\title{
Nitrogen fertilization and leaf spraying with Azospirillum brasilense in wheat: effects on mineral nutrition and yield
}

\author{
Adubação nitrogenada e pulverização foliar de Azospirillum brasilense em trigo: efeitos na nutrição \\ mineral e produtividade
}
Marcos Renan Besen*, Antonio Feijo Goes Neto, Michel Esper Neto, Eder Junior de Oliveira Zampar, Eunápio José de Oliveira Costa, Vitor Rodrigues Cordioli, Tadeu Takeyoshi Inoue, Marcelo Augusto Batista

Universidade Estadual de Maringá, Maringá, PR, Brasil. * Author for correspondence: marcos.besen@hotmail.com

Submission: 12/05/2020 / Acceptance: 02/09/2020

\begin{abstract}
The use of Azospirillum brasilense has the potential to improve plant nitrogen $(\mathrm{N})$ use efficiency, while a better understanding of alternative management practices with inoculation is necessary. The aim was to examine the effects of the leaf application of $A$. brasilense in association with nitrogen fertilization on the wheat crop. The experiment was conducted in Lidianópolis, Paraná, Brazil, in a completely randomized block design with four replications. The treatments included four doses of $A$. brasilense for leaf application $\left(0,200,400\right.$, and $\left.600 \mathrm{ml} \mathrm{ha}^{-1}\right)$ and four doses of $\mathrm{N}\left(0,40,80\right.$, and $\left.120 \mathrm{~kg} \mathrm{~N} \mathrm{ha}^{-1}\right)$. The nutritional content, yield components, quality, and yield of the wheat crop were evaluated. There was no interaction among the factors, nor did the treatments have an isolated effect on spike length, the number of spikelets per spike, spikes per $\mathrm{m}^{2}$, thousand grain weight, and test weight. However, doses of $A$. brasilense increased calcium and magnesium absorption at 283 and $380 \mathrm{ml} \mathrm{ha}^{-1}$, respectively. Similarly, nitrogen application increased the content of calcium, magnesium, and copper in the leaf at 61,47 , and $49 \mathrm{~kg} \mathrm{~N} \mathrm{ha}^{-1}$, respectively. Nitrogen also increased the number of grains per spike and yield at 56 and $54 \mathrm{~kg} \mathrm{~N} \mathrm{ha}^{-1}$, respectively. Yield correlated with the number of grains per spike and the manganese and copper content in the leaf. The results demonstrate that the inoculation of leaves with $A$. brasilense favored a higher absorption of divalent cationic macronutrients and that $\mathrm{N}$ was fundamental to increasing the yield, with the best responses observed between 47 and $61 \mathrm{~kg} \mathrm{ha}^{-1}$.
\end{abstract}

KEYWORDS: auxin, diazotrophs, nitrogen use efficiency, mineral nutrition, Triticum aestivum.

\section{RESUMO}

O uso de Azospirillum brasilense apresenta potencial em melhorar a eficiência de uso do nitrogênio $(\mathrm{N})$, sendo necessário melhor compreensão de formas alternativas de inoculação, visto que o tratamento químico de sementes pode comprometer a eficiência das bactérias. $O$ objetivo foi avaliar os efeitos do $A$. brasilense aplicado via foliar associado a adubação nitrogenada na cultura do trigo. $O$ experimento foi implantado em Lidianópolis, no estado do Paraná, Brasil, em blocos completos com tratamentos ao acaso e quatro repetições, sendo os tratamentos: quatro doses de $A$. brasilense via foliar $(0,200,400$ e $600 \mathrm{ml}$ $\left.\mathrm{ha}^{-1}\right)$ e quatro doses de $\mathrm{N}\left(0,40,80 \mathrm{e} 120 \mathrm{~kg} \mathrm{~N} \mathrm{ha}^{-1}\right)$. Foram avaliados os teores nutricionais, componentes de rendimento, qualidade e produtividade. Não houve interação entre os fatores, tampouco efeito isolado dos tratamentos para comprimento da espiga, número de espiguetas por espiga, espigas por $\mathrm{m}^{2}$, massa de mil grãos e peso de hectolitro. Todavia as doses de A. brasilense, aumentaram a absorção de $\mathrm{Ca}$ e $\mathrm{Mg}$ até a dose de 283 e $380 \mathrm{ml} \mathrm{ha}^{-1}$, respectivamente. De modo similar, o $\mathrm{N}$ aplicado aumentou os teores foliares de cálcio, magnésio, além de cobre até a dose de 61,47 e $49 \mathrm{~kg} \mathrm{ha}^{-1}$ de $\mathrm{N}$, respectivamente. $\mathrm{O} \mathrm{N}$ também incrementou o número de grãos por espiga e a produtividade até a dose 56 e $54 \mathrm{~kg} \mathrm{~N} \mathrm{ha}^{-1}$, respectivamente, porém a eficiência de uso de $\mathrm{N}$ diminuiu com o aumento da dose. A produtividade se correlacionou com número de grãos por espiga e teores foliares de manganês e cobre. Os resultados demonstram que a inoculação com $A$. brasilense foliar foi favorável a maior absorção de macronutrientes catiônicos divalentes, e $\circ \mathrm{N}$ fundamental para aumento da produtividade, sendo as melhores respostas obtidas entre as doses de 47 a $61 \mathrm{~kg} \mathrm{ha}^{-1}$.

PALAVRAS-CHAVE: auxina, bactérias diazotróficas, eficiência de uso do nitrogênio, nutrição mineral, Triticum aestivum 


\section{INTRODUCTION}

Brazil sets itself apart from the world as one of the largest food producers. However, with regard to the wheat crop, national production has only supplied 50\% of national demand (CEPEA 2018), which makes the country one of the largest importers of wheat (ABITRIGO 2017). In the 2017 harvest, the area designated for the wheat crop corresponded to approximately 2.0 million ha and resulted in a yield of 5.4 thousand tons, culminating in an average yield of $2225 \mathrm{~kg} \mathrm{ha}^{-1}$ (CONAB 2018).

The state of Paraná in Brazil is the biggest cereal grain producer and has the largest cultivated area. Therefore, wheat is a very important winter crop for the South of the country and one of the few sources of income during the cold season (RIBEIRO et al. 2018). This is why it is necessary to develop techniques that allow for better use of the cultivated areas, particularly correct soil fertility management and mineral nutrition.

Nitrogen $(\mathrm{N})$ is the most required nutrient for the wheat crop, and its extraction and exportation are in the order of 28 and $20 \mathrm{~kg} \mathrm{~N}$ for each ton of grain produced, respectively (SBCS/NEPAR 2017). According to MOREIRA \& SIQUEIRA (2002), less than half of the $N$ applied in the soil is absorbed by the plants, the rest is immobilized or lost through volatilization and/or leaching. In this sense, using biological resources for $\mathrm{N}$ management has the potential to increase $\mathrm{N}$ use efficiency (FERNANDES 2016).

The use of Azospirillum brasilense is an alternative for reducing the application of $\mathrm{N}$ fertilizer, either through biological $\mathrm{N}$ fixation or greater $\mathrm{N}$ use efficiency due to root system growth (BASHAN \& de-BASHAN 2010). Moreover, bacteria of the genus Azospirillum have the potential to stimulate plant development through multiple mechanisms, including biosynthesis of phytohormones, better nitrogen nutrition, stress mitigation, and biological control of pathogenic microbiota (BASHAN \& de-BASHAN 2010). The main hormone produced by strains of Azospirillum is the auxin, IAA, which is responsible for inducing elongation and cell division.

A meta-analysis by VERESOGLOU \& MENEXES (2010) found that inoculation with Azospirillum spp. provided an average increase of $8.9 \%$ in wheat grain yield compared to the trials without inoculation. DÍAZZORITA \& CANIGIA (2009) performed 297 experiments under field conditions in Argentina between 2002 and 2006 in order to examine the effect of inoculation with $A$. brasilense strain INTA Az-39. According to the authors, there was a positive inoculation response in $70 \%$ of the sites and increases in grain yield of $8 \%$.

Inoculation with Azospirillum is commonly applied to the seed, and the inoculant can be applied in either a liquid or solid form. However, the bacteria's contact with pesticides, such as insecticides and fungicides, that are used in seed treatments may compromise the inoculation technique (FUKAMI et al. 2016, MUNARETO et al. 2018), thereby requiring alternative methods to increase the bacteria's efficiency. In recent years, leaf application of Azospirillum has been the object of several studies (PEREIRA et al. 2017, RIBEIRO et al. 2018, CORREIA et al. 2020).

In a study by OFFEMANN (2015), leaves were sprayed with $A$. brasilense, which promoted increases in the average internode length, average spike length, leaves, spikes, root dry mass, root volume, and the leaves' N content. MARKS et al. (2015) found that spraying leaves with Azospirillum resulted in significant increases in shoot dry mass compared to the controls without inoculation. RIBEIRO et al. (2018) showed that inoculation in wheat seeds and leaves with $A$. brasilense promoted plant height growth but did not influence yield components and grain yield. Additionally, according to the authors, there was no conformity in the inoculation techniques, presenting varying results in the two years of research.

Therefore, this study hypothesized that the leaf application of $A$. brasilense favors plant nutrition and has positive effects on crop yield components by reducing the dose of mineral $\mathrm{N}$. The aim was to evaluate the effect of leaf inoculation with $A$. brasilense in association with $\mathrm{N}$ rates in the wheat crop.

\section{MATERIAL AND METHODS}

The experiment was conducted under field conditions in a no-till system in Lidianópolis, Paraná, Brazil, located at an altitude of 539 meters at the geographical coordinates $24^{\circ} 05^{\prime} 36^{\prime \prime} \mathrm{S}, 51^{\circ} 41^{\prime} 85^{\prime \prime} \mathrm{W}$. The soil of the area was classified as Dystrophic Red Oxisol (SANTOS et al. 2013) with a composition of $83 \%$ clay, $7 \%$ sand, and $10 \%$ silt. The chemical characteristics prior to the experiment are presented in Table 1.

According to the Köppen-Geiger classification, the region has a humid subtropical climate (CFa), whose characteristics include average temperatures below $18^{\circ} \mathrm{C}$ in the colder months and above $22^{\circ} \mathrm{C}$ in the warmer months. Climate data on the precipitation and temperatures during the experiment were obtained from INMET (National Institute of Meteorology) and are shown in Figure 1. The sequential water balance was calculated using a program developed by ROLIM et al. (1998). Prior to the experiment, a wheat-soybean succession had been cultivated in the area in question in the last five years. 
Table 1. Chemical traits of the dystrophic Red Oxisol prior to the experiment at layers $0-10 \mathrm{~cm}, 10-20 \mathrm{~cm}$, and $20-40 \mathrm{~cm}$.

\begin{tabular}{|c|c|c|c|c|c|c|c|c|c|c|c|c|}
\hline \multirow{2}{*}{$\begin{array}{l}\text { Layer. } \\
(\mathrm{cm})\end{array}$} & $P$ & $\mathrm{SO}_{4}{ }^{2-}$ & $p$ & & $\mathrm{H}+\mathrm{Al}$ & $\mathrm{Al}^{3+}$ & $\mathrm{K}^{+}$ & $\mathrm{Ca}^{2+}$ & $\mathrm{Mg}^{2+}$ & \multirow[t]{2}{*}{ CEC } & \multirow{2}{*}{$\begin{array}{c}\text { BS } \\
\%\end{array}$} & \multirow{2}{*}{$\begin{array}{c}\mathrm{C} \\
\mathrm{g} \mathrm{dm}^{-3}\end{array}$} \\
\hline & \multicolumn{2}{|c|}{$----m g ~ d m^{-3}--$} & $\mathrm{CaCl}_{2}$ & $\mathrm{H}_{2} \mathrm{O}$ & ---- & 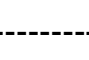 & $--\mathrm{cmo}$ & $\mathrm{dm}^{-3}-$ & -----. & & & \\
\hline $0-10$ & 22.72 & 7.42 & 5.3 & 6.2 & 5.72 & 0.00 & 1.00 & 10.74 & 3.98 & 15.72 & 73.32 & 9.35 \\
\hline $10-20$ & 6.61 & 5.58 & 5.1 & 5.9 & 6.79 & 0.00 & 0.52 & 11.18 & 2.86 & 14.56 & 68.20 & 17.78 \\
\hline $20-40$ & 5.17 & 8.15 & 5.6 & 6.3 & 4.68 & 0.00 & 0.38 & 12.12 & 3.21 & 15.71 & 77.05 & 12.87 \\
\hline
\end{tabular}

$\mathrm{Al}^{3+}, \mathrm{Ca}^{2+}$ e $\mathrm{Mg}^{2+}: 1 \mathrm{M} \mathrm{KCl}$ extractor; $\mathrm{P}$ and $\mathrm{K}^{+}$: Melich-1 extractor; Carbon (C): Walkey Black; CEC: cation exchange capacity; BS: Base saturation.

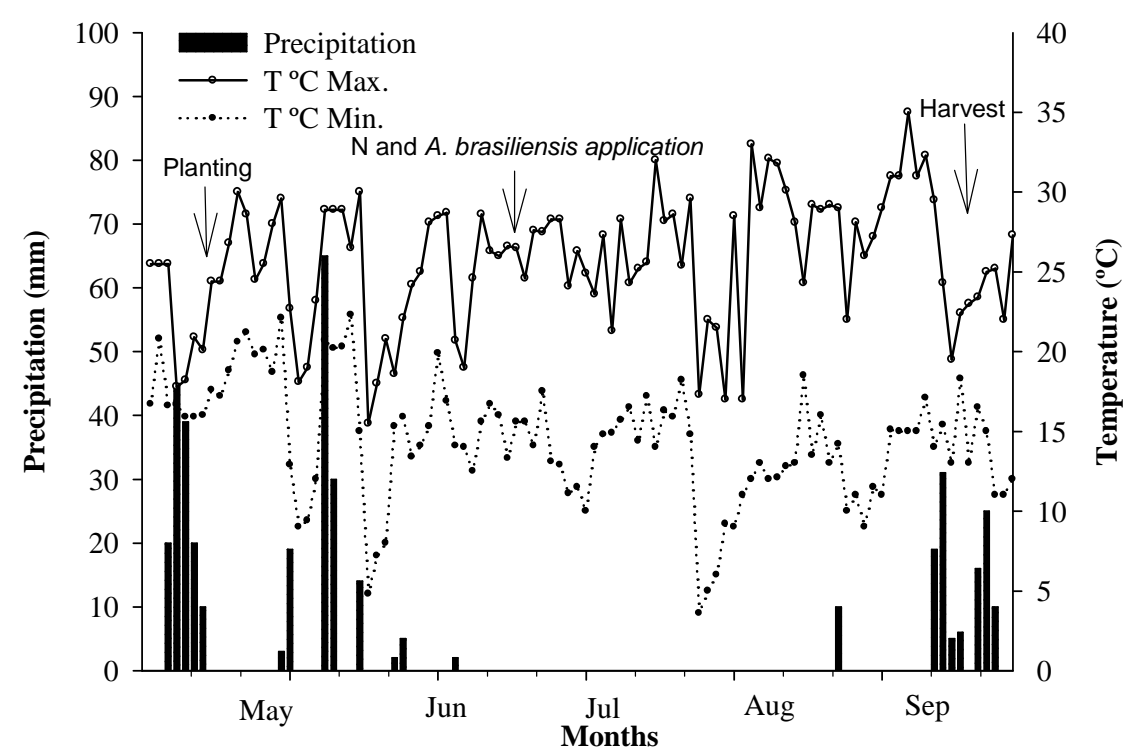

Figure 1. Precipitation and maximum and minimum temperatures during the experimental period.

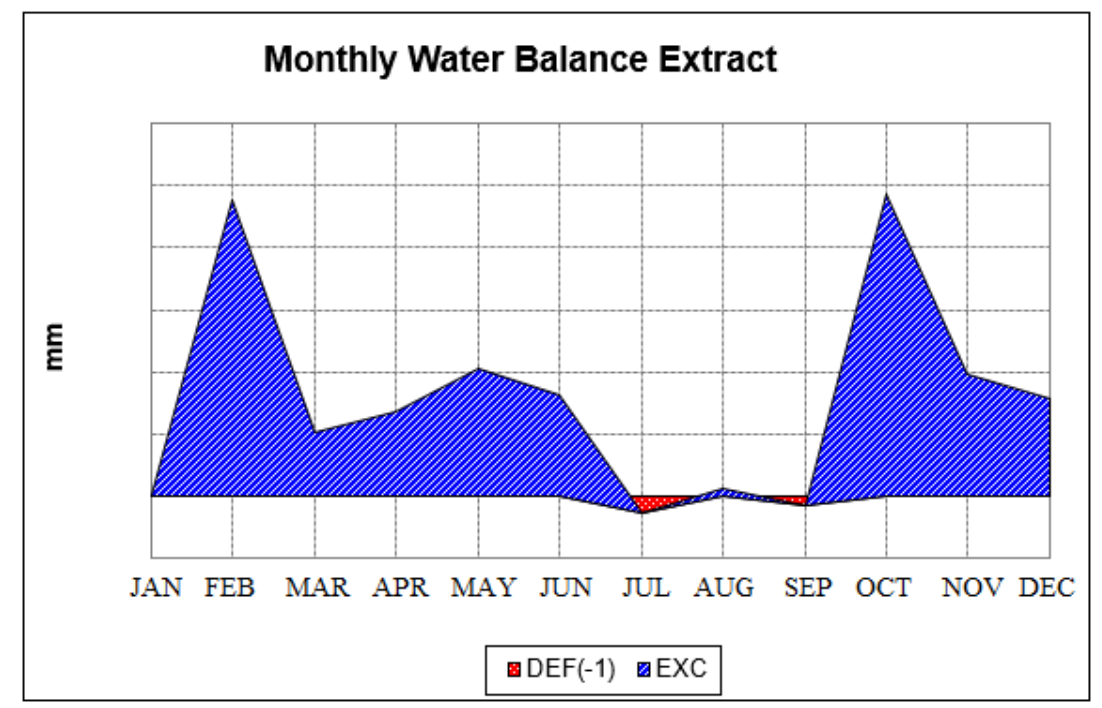

Figure 1. Monthly water balance of experimental area, water deficit (DEF), and excess water (EXC).

A completely randomized block design was applied in a $4 \times 4$ factorial scheme. The first factor consisted of doses of $\mathrm{N}\left(0,40,80\right.$, and $\left.120 \mathrm{~kg} \mathrm{~N}^{-1}\right)$, while the second consisted of doses of standard inoculant containing Azospirillum brasilense $\left(0,200,400\right.$, and $\left.600 \mathrm{ml} \mathrm{ha}^{-1}\right)$, totaling 16 treatments in four replications. 
The experimental units contained 18 rows that were $5 \mathrm{~m}$ in length and spaced $0.17 \mathrm{~m}$ apart, totaling an area of $15.3 \mathrm{~m}^{2}$. The wheat cultivar (Triticum aestivum L.) TBIO Iguaçu was selected. The wheat was sowed mechanically on May 10, 2017, with a population of 350 plants per $\mathrm{m}^{2}$. Fertilization was applied at sowing with $250 \mathrm{~kg} \mathrm{ha}^{-1}$ of NPK 10-15-15. The treatments were applied to the total area in the tillering stage. The doses of inoculant were diluted in water and applied to the leaves at night through a spray bar system with $\mathrm{CO}_{2}$ pressurization, regulated to a flow of $100 \mathrm{~L} \mathrm{ha}^{-1}$. The Masterfix Gramíneas ${ }^{\circledR}$ inoculant was used at a concentration of 100 million cells of $A$. brasilense per ml. Urea was used for nitrogen fertilization (45\% $\mathrm{N})$. The cultural trails followed technical recommendations.

When $50 \%$ of the wheat plants were in the flowering stage, leaf tissue samples were taken, and fifty flag leaves per experimental unit were randomly collected. After taking the leaf samples, the leaves were dried to constant mass in a forced-air oven at $65^{\circ} \mathrm{C}$. A Wiley mill was then used to grind the materials, which were subsequently weighed and digested with nitric-perchloric acid in order to determine elements of $\mathrm{Ca}$, $\mathrm{Mg}, \mathrm{K}, \mathrm{P}$, and S (MALAVOLTA et al. 1997). Ca and Mg content were determined by atomic absorption spectrophotometry (AAS) with acetylene/air. $\mathrm{P}$ was assessed by the vanadate yellow colorimetric method, $\mathrm{S}$ by turbidimetry, and $\mathrm{K}$ by flame photometry. After sulfuric acid digestion, $\mathrm{N}$ was determined by the microKjeldahl method (MALAVOLTA et al. 1997).

At physiological maturity, the number of spikes per $\mathrm{m}^{2}$ was calculated by counting two linear meters in two central rows per plot. Fifteen spikes per experimental unit were collected to evaluate spike length (cm), number of grains per spike, and number of spikelets per spike.

The wheat was harvested on September 22, 2017, totaling a useful area of $7.48 \mathrm{~m}^{2}$. The results were extrapolated to $\mathrm{kg} \mathrm{ha}^{-1}$, and the thousand grain weight was determined. The test weight, which involves a physical analysis of the grain, was measured, with the mass of 100 liters of wheat expressed in $\mathrm{kg} \mathrm{hl}^{-1}$.

Based on FAGERIA \& BALIGAR (2005), nitrogen use efficiency (NUE) was calculated: where NUE = (GYwn - GYon) / (QNa), expressed in kg kg ${ }^{-1}$; GYwn represents grain yield with nitrogen fertilizer; GYon is grain yield without nitrogen fertilizer; and $\mathrm{QNa}$ is the quantity of applied $\mathrm{N}$ in $\mathrm{kg}$.

The data were initially tested for error normality and homogeneity of variance by the Shapiro-Wilk test and Bartlett's test, respectively. There was no need for data transformation, and the Anova assumptions were met. Analysis of variance by Snedcor's $\mathrm{F}$ distribution at $5 \%$ significance level was performed using the data. Regression analysis was applied to test the linear and quadratic effect of the quantitative factors. The Pearson correlation coefficient was also used to measure the association between the response variables.

\section{RESULTS AND DISCUSSION}

Weather conditions were not ideal for the wheat crop's full development (Figure 1). The water balance revealed that the absence of precipitation events during July and September culminated in a water deficit during the flowering and grain-filling stages (Figure 2). The water requirement for the wheat crop is 450 to $600 \mathrm{~mm}$, depending on the climate and the duration of the cycle (DOORENBOS \& KASSAM 1979), with an average consumption of $3.0 \mathrm{~mm}^{-1}$ day $^{-1}$ (LIBARDI \& COSTA 1997). Although cumulative precipitation during the cultivation period reached $351 \mathrm{~mm}$, the precipitation events were poorly distributed. There was excess water at the beginning of crop development (Figure 2) and only $122 \mathrm{~mm}$ between the tillering stage, when the treatments were applied, and the grain ripening stage. The water deficit limited the average yield of the experimental area $\left(1125 \mathrm{~kg} \mathrm{ha}^{-1}\right)$, which was lower than Paraná's state average (2308 kg ha $\left.{ }^{-1}\right)(\mathrm{CONAB}$ 2018).

There was no interaction between $A$. brasilense and $\mathrm{N}$ for any of the response variables in question $(p<0.05)$. None of the treatments had an effect on spike length, the number of spikelets per spike, the number of spikes per $\mathrm{m}^{2}$, thousand grain weight, test weight, or on the leaf's $\mathrm{N}, \mathrm{P}, \mathrm{K}, \mathrm{Fe}, \mathrm{Mn}$, and $\mathrm{Zn}$ content (Table 2). However, $A$. brasilense had an isolated effect on the leaf's $\mathrm{Ca}$ and $\mathrm{Mg}$ content, and $\mathrm{N}$ had an isolated effect on yield, the number of grains per spike, and the leaf's $\mathrm{Ca}, \mathrm{Mg}$, and $\mathrm{Cu}$ content.

Spraying leaves with $A$. brasilense increased their $\mathrm{Ca}$ and $\mathrm{Mg}$ content, while the maximum dose for each was 283 and $380 \mathrm{ml} \mathrm{ha}^{-1}$, respectively (Figure $3 A$ and $3 B$ ). The results are promising since, in this study, leaf spraying with a dose of $200 \mathrm{ml} \mathrm{ha}^{-1}$ allowed the $\mathrm{Mg}$ content to reach the crop's sufficiency range, 1.5 to $4 \mathrm{~g} \mathrm{~kg}^{-1}$ (SBCS/NEPAR 2017). For the other doses, the levels were below the sufficiency range. CREUS et al. (2004) found an increase in $\mathrm{Mg}, \mathrm{Ca}$, and $\mathrm{K}$ content in wheat grains compared to the plants without inoculation. ARAÚJO et al. (2013) observed that the $\mathrm{Ca}$ and $\mathrm{Mg}$ (in addition to $\mathrm{N}$ and $\mathrm{K}$ ) content in corn kernels increased with the inoculation of $A$. brasilense and Herbaspirillum seropedica. GALINDO et al. (2019) observed that inoculation with $A$. brasilense enabled a higher accumulation of $\mathrm{Cu}, \mathrm{Fe}, \mathrm{Mn}$, and $\mathrm{Zn}$ in straw and of $\mathrm{Mn}$ and $\mathrm{Zn}$ in grains, regardless of the dose of $\mathrm{N}$. 
Table 2. Average values for spike length (SL), number of spikelets per spike (NSS), number of spikes per $\mathrm{m}^{2}$ $\left(\right.$ spi $\left.\mathrm{m}^{2}\right)$, thousand grain weight (TGW), test weight (TW), and the leaf's nitrogen (N), phosphorus (P), potassium $(\mathrm{K})$, iron $(\mathrm{Fe})$, manganese $(\mathrm{Mn})$, and zinc $(\mathrm{Zn})$ content after application of $\mathrm{N}$ and $A$. brasilense.

\begin{tabular}{|c|c|c|c|c|c|c|c|c|c|c|c|}
\hline Variable & $\begin{array}{c}\mathrm{SL} \\
(\mathrm{cm})\end{array}$ & NSS & $\begin{array}{l}\text { Spi } \\
\left(\mathrm{m}^{2}\right)\end{array}$ & $\begin{array}{l}\text { TMG } \\
\left(\mathrm{g}^{-1}\right)\end{array}$ & $\begin{array}{c}\mathrm{PH} \\
\mathrm{kg} / \mathrm{hl}\end{array}$ & $\mathrm{N}$ & -----g kg ${ }^{-1}----$ & K & $\mathrm{Fe}$ & ------mg ${ }^{-1}-----$ & $\mathrm{Zn}$ \\
\hline Average & 7.66 & 14.1 & 300.60 & 35.50 & 84.87 & 36.35 & 1.83 & 16.32 & 329 & 100.07 & 29.77 \\
\hline SD & 0.44 & 0.83 & 32.40 & 1.56 & 1.66 & 1.57 & 0.44 & 2.88 & 62 & 19.66 & 4.63 \\
\hline CV\% & 5.88 & 17.15 & 9.27 & 4.47 & 1.96 & 23.03 & 14.40 & 17.84 & 19.30 & 19.19 & 1.58 \\
\hline
\end{tabular}

$\mathrm{SD}=$ Standard deviation; $\mathrm{CV}(\%)=$ coefficient of variation.

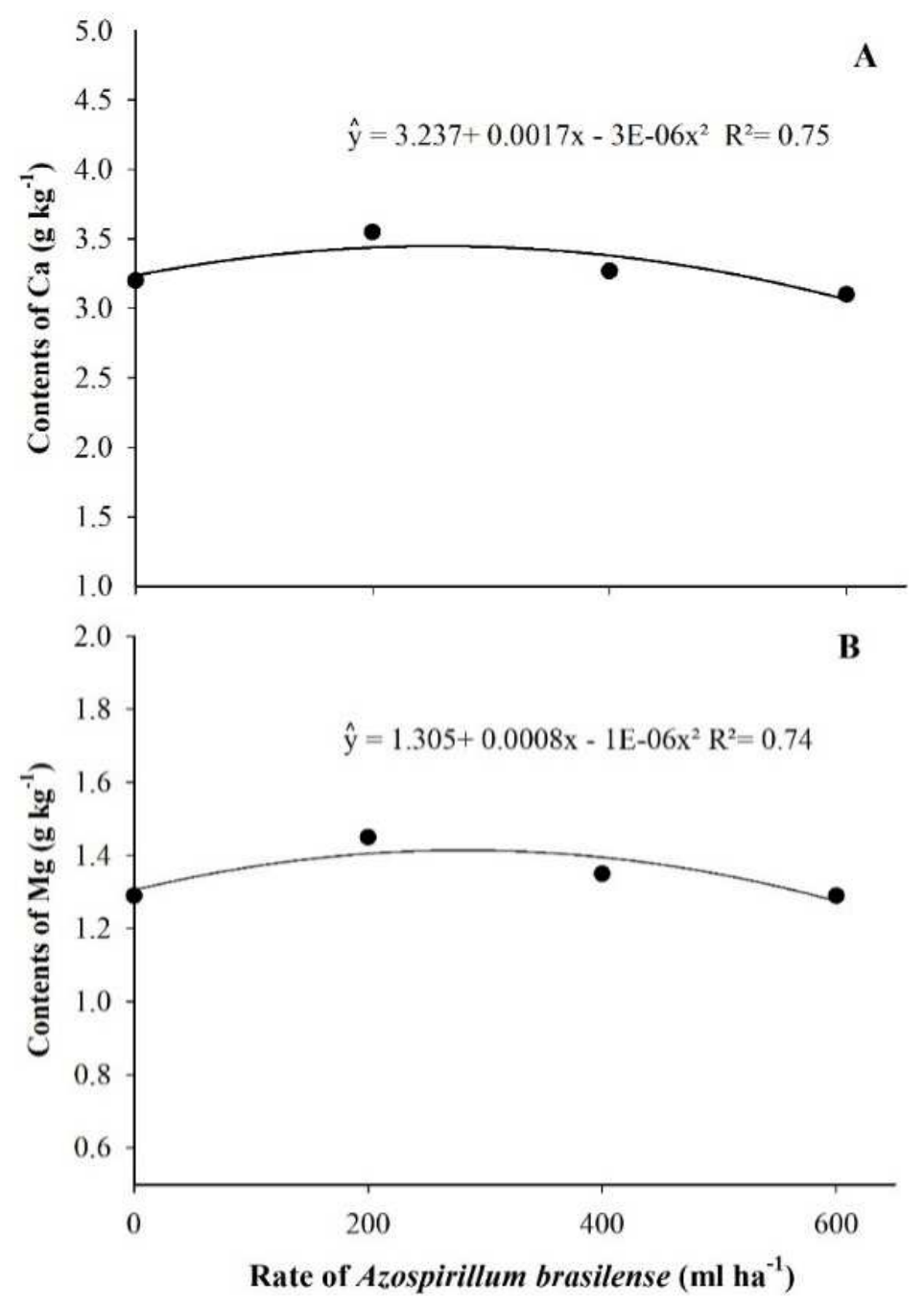

Figure 1. Leaf's calcium $(\mathrm{A})$ and magnesium $(\mathrm{B})$ content after spraying leaf with $A$. brasilense.

It is assumed that these results are due to root growth stimulus. NOZAKI et al. (2014) observed that seed inoculation with Azospirillum increased the wheat plant's dry mass, fresh mass, and root size. The Millet root morphology changed when plants were inoculated. The number of secondary roots increased, and all the lateral roots were densely covered with root hair (TIEN et al. 1979). Moreoever, root system development is important for the absorption of elements that meet the root by root interception, such as $\mathrm{Ca}$ and $\mathrm{Mg}$, which, although largely absorbed by mass flow, are also absorbed by root interception.

Root growth is due to the synthesis of phytohormones produced by bacteria, mainly indoleacetic acid, gibberellins, and cytokines (TIEN et al. 1979). In addition, the application of Azospirillum is also responsible for higher plant water and mineral absorption rates (OKON \& KAPULNIK 1986, CASANOVAS et al. 2002) and an increased tolerance to abiotic stresses such as drought (CASSÁN et al. 2009, KIM et al. 2012). 
According to DOBBELAERE et al. (2002), the benefits of Azospirillum on plant growth are mainly due to morphological and physiological changes in inoculated roots.

However, bacteria of the genus Azospirillum are capable of synthesizing substances such as cadaverine (CASSÁN et al. 2009). All-natural polyamines, including cadaverine, strongly inhibit the opening and closing of stomata by regulating potassium channels in guard cells, an important effect under abiotic stress conditions (LIU et al. 2000), such as the water deficit between July and September. Plant growthpromoting bacteria such as Azospirillum may play a strategic role in stress conditions due to the activation of various physiological and biochemical mechanisms of tolerance in plants, called induced systemic tolerance (YANG et al. 2009, KIM et al. 2012).

Therefore, we can expect a higher probability of favorable responses to $A$. brasilense when plants are affected by biotic or abiotic stresses. In a study by GALINDO et al. (2015a) with irrigated wheat, the duration of the leaf application of $A$. brasilense did not influence the leaf's nitrogen, phosphorus, potassium, calcium, magnesium, sulfur, boron, copper, iron, manganese, and zinc content or the yield or yield components (GALINDO et al. 2015b).

The positive effects of inoculation with Azospirillum in wheat plants are more pronounced when there is low or moderate fertilization, which points to the importance of the bacteria's role in stimulating root development rather than the fixation of atmospheric $N$ itself (DOBBELAERE et al. 2002). In this sense, without aluminum, a high availability of nutrients $(\mathrm{P}, \mathrm{Ca}, \mathrm{Mg}$, and $\mathrm{K})$, and organic matter, which is indicative of the availability of $\mathrm{N}$, the high soil fertility is remarkable (Table 1).

Increased doses of $\mathrm{N}$ increased the leaf's $\mathrm{Ca}, \mathrm{Mg}$, and Copper content quadratically, with maximum values at 61,47 , and $49 \mathrm{~kg} \mathrm{~N}$ ha $^{-1}$, respectively (Figure 4). ESPíNDULA et al. (2010) observed $\mathrm{N}$ rates and an increase in the $\mathrm{Ca}$ and $\mathrm{Cu}$ content of wheat seeds but saw no effects for $\mathrm{Mg}$. The results suggest that the increased $\mathrm{Cu}$ content in leaf tissue may be related to higher nutrient absorption as a function of nitrogen fertilization. The use of amide or ammonium fertilizers, which generate ammonium by hydrolysis, intensifies soil acidification because, in the nitrification process, each $\mathrm{NH}_{4}{ }^{+}$molecule that is oxidized to $\mathrm{NO}_{3}{ }^{-}$releases two protons $\left(\mathrm{H}^{+}\right)$. Thus, soil acidification increases the availability of cationic micronutrients such as $\mathrm{Cu}$ (MORAGHAN \& MASCAGNI Jr. 1991).

As for the isolated effects of the application of $\mathrm{N}$, there was an increase in the number of grains per spike (NGS) and in yield, with a quadratic model adjustment, where the highest NGS and the maximum yield corresponded to the doses 56 and $54 \mathrm{~kg} \mathrm{~N} \mathrm{ha}^{-1}$, respectively (Figure 5). In a study by BESEN et al. (2018), N application increased the number of grains per spike, spike length, and the number of spikes per $\mathrm{m}^{2}$. RONSANI et al. (2018) examined $\mathrm{N}$ in doses of $0,30,60$, and $120 \mathrm{~kg} \mathrm{ha}^{-1}$ and noted a linear increase in spike length, spikelets, grains, thousand grain weight, and yield.

The influence of $\mathrm{N}$ on wheat yield components may be related to a higher interception of solar radiation and to an increase in leaf area index, as indicated by the plant's growth in height (HEINEMANN et al. 2006), thereby resulting in a greater yield (BESEN et al. 2018). Furthermore, $\mathrm{N}$ performs vital functions for the plant in the structural functions of amino acids, proteins, glycols, lipoproteins, vitamins, and it is also active in the constitution of all enzymes and is responsible for activating a multitude of them (MALAVOLTA et al. 1997).

SILVA \& PIRES (2017) analyzed the same $N$ rates and also identified a quadratic response in grain yield. In addition, the authors found that the supply of $\mathrm{N}$ with urea was not effective in increasing the effects of inoculation with Azospirillum on wheat yield and that inoculation with $A$. brasilense does not substitute nitrogen fertilization. RIBEIRO et al. (2018) also reported that leaf spraying with $A$. brasilense had no effect on yield or yield components. However, PEREIRA et al. (2017) reported positive results in the number of grains per spike from the leaf application of $400 \mathrm{ml} \mathrm{ha}^{-1}$.

NUE decreased linearly as the $N$ dose increased, registering the values $4.84,1.22$, and $0.51 \mathrm{~kg} \mathrm{~kg}^{-1}$ for the doses 40,80 , and $120 \mathrm{~kg} \mathrm{ha}^{-1}$, respectively (Figure 6). The results corroborate findings by CAZETTA et al. (2007), who examined doses of $\mathrm{N}$ up to $120 \mathrm{~kg} \mathrm{ha}^{-1}$ and also observed a decrease in NUE, where the greatest NUE corresponded to the lowest dose of $\mathrm{N}$, as in the present study.

Although $\mathrm{N}$ and $A$. brasilense had no effect on the wheat's test weight (TW), with an average value of $84 \mathrm{~kg} \mathrm{hL}^{-1}$ (Table 1), MENDES et al. (2011) observed a positive effect from the application of $A$. brasilense through seed priming. PEREIRA et al. (2017) found that $A$. brasilense favored this variable in the lowest doses of mineral $\mathrm{N}$, regardless of the mode of application (seed, leaf, or furrow). TW is indicative of wheat quality and yield. In Brazil, a TW of $78 \mathrm{~kg} \mathrm{hL}^{-1}$ or higher for clean grain at $13 \%$ humidity is considered the reference value for high quality industrial wheat (PEREIRA et al. 2017). Even though no differences were found in the treatments, the wheat grains demonstrated high quality. 


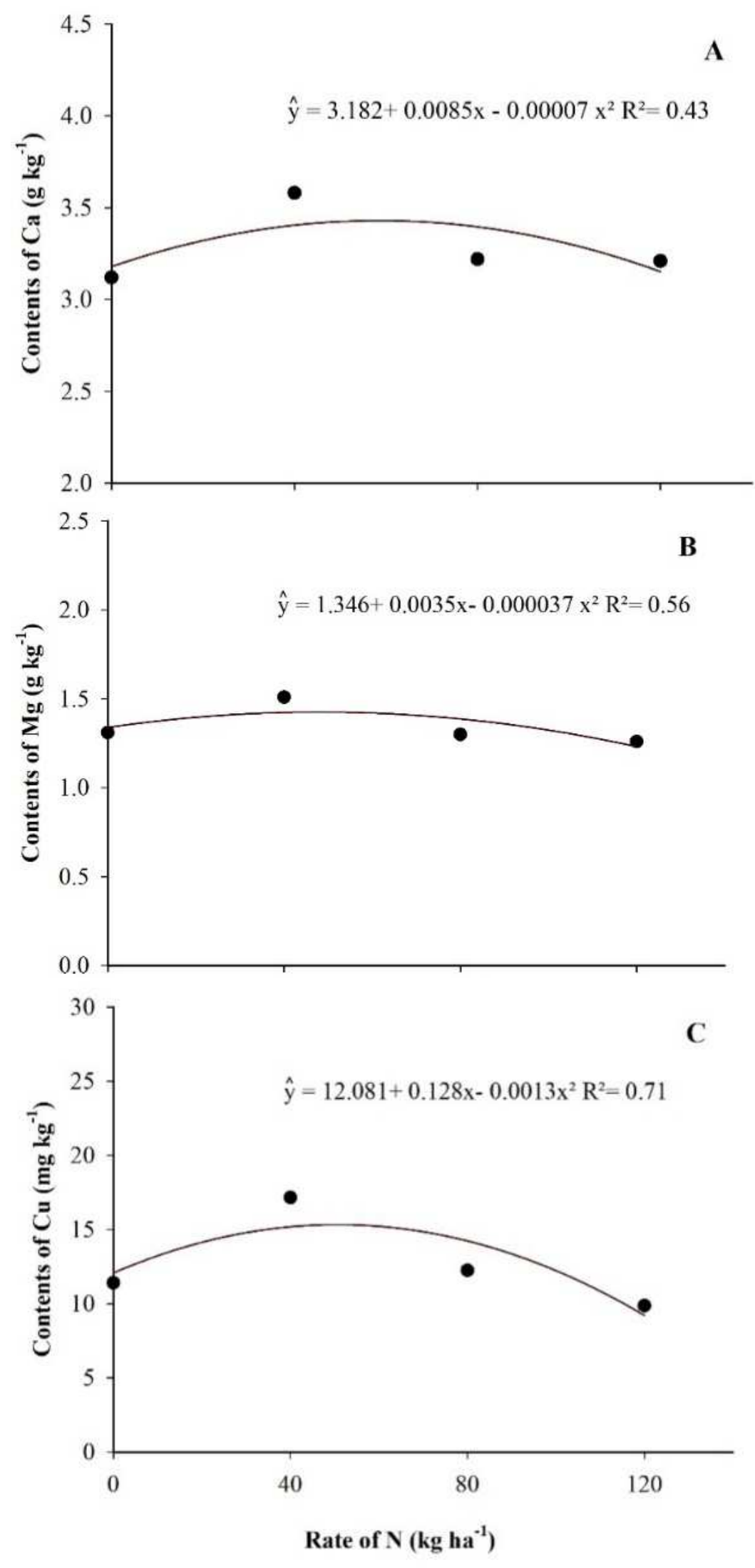

Figure 2. Leaf's (A) calcium, (B) magnesium, and (C) copper content as a function of $\mathrm{N}$ application in doses.

Yield had a positive correlation with the number of grains per spike and the $\mathrm{Cu}$ and $\mathrm{Mn}$ content in the leaf (Table 3). In a no-till system, MOREIRA et al. (2019) also found that wheat grain yield was associated with the availability of $\mathrm{Cu}$. With the exception of $\mathrm{N}$ and $\mathrm{P}$ levels, the other nutrients $(\mathrm{K}, \mathrm{Ca}, \mathrm{Mg}, \mathrm{Fe}, \mathrm{Zn}, \mathrm{Cu}$, and $\mathrm{Mn}$ ) showed a positive association, with the highest correlation coefficient between $\mathrm{Mg}$ and $\mathrm{Mn}(0.95)$. 


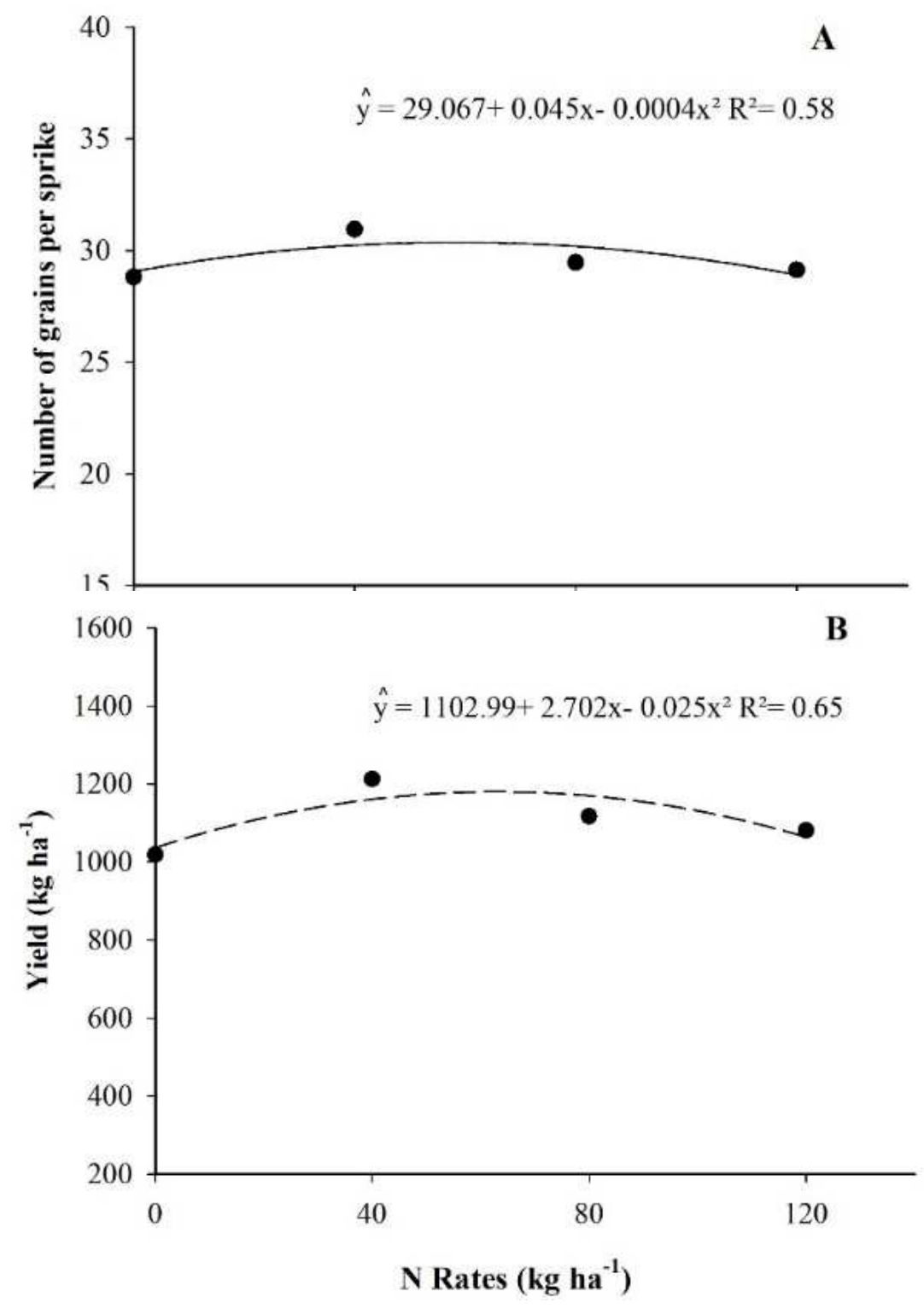

Figure 3. Number of grains per spike (A) and yield (B) as a function of $\mathrm{N}$ application in doses.

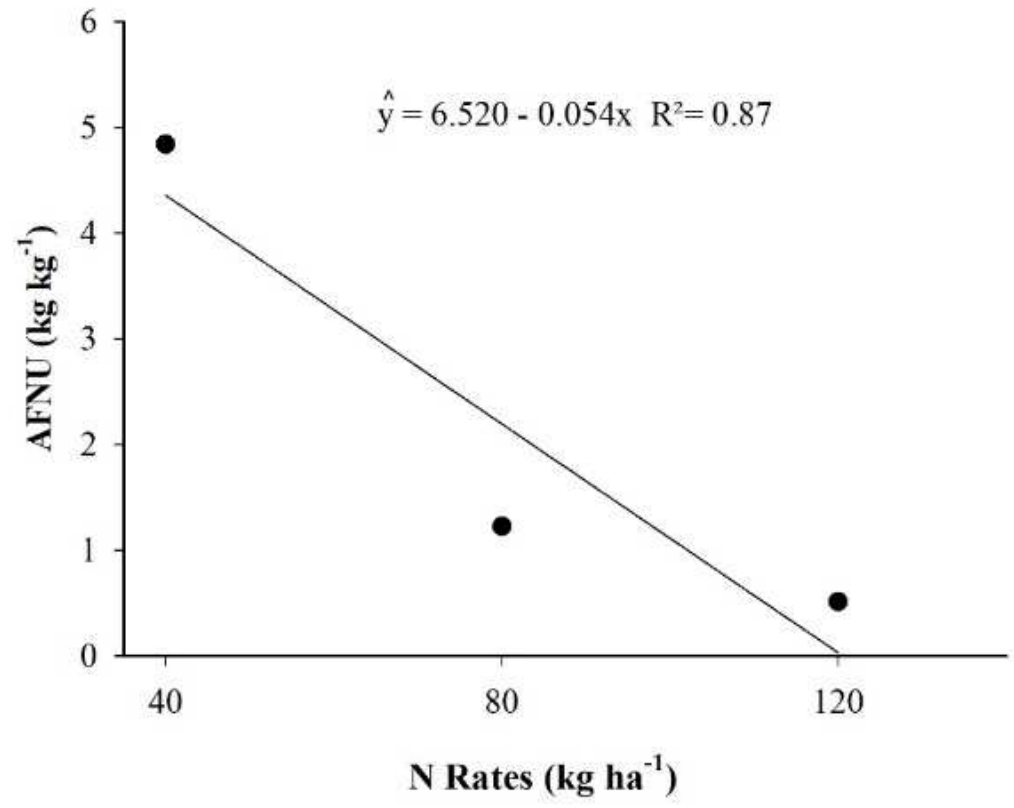

Figure 6. Nitrogen use efficiency after applying different doses of $\mathrm{N}$ using urea. 
Table 3. Pearson correlation matrix between the response variables: Yield (Yie); thousand grain weight (TGW); test weight (TW); spikes per $\mathrm{m}^{2}$ (spi $\mathrm{m}^{2}$ ); spike length (SL); number of spikelets per spike (NSS); number of grains per spike (NGS); and leaf's nitrogen (N), phosphorus (P), potassium (K), calcium $(\mathrm{Ca})$, magnesium $(\mathrm{Mg})$, iron (FE), zinc $(\mathrm{Zn})$, copper $(\mathrm{Cu})$, and manganese $(\mathrm{Mn})$ content.

\begin{tabular}{|c|c|c|c|c|c|c|c|c|c|c|c|c|c|c|c|}
\hline & TMG & $\overline{\mathrm{WH}}$ & spi m² & SL & NSS & NGS & $\mathrm{N}$ & $P$ & K & $\mathrm{Ca}$ & $\mathrm{Mg}$ & $\mathrm{Fe}$ & $\mathrm{Zn}$ & $\mathrm{Cu}$ & $\mathrm{Mn}$ \\
\hline Yie & 0.29 & 0.31 & -0.12 & 0.21 & -0.04 & $0.47^{*}$ & 0,11 & 0,41 & 0,35 & 0,38 & 0,37 & 0,27 & 0,38 & $0,61^{* *}$ & $0,49^{*}$ \\
\hline TMG & & 0.02 & 0.18 & $0.45^{*}$ & 0.04 & 0.14 & 0.07 & -0.08 & 0.01 & -0.01 & -0.07 & 0.11 & 0.18 & 0.07 & 0.08 \\
\hline $\mathrm{PH}$ & & & -0.02 & -0.13 & -0.12 & 0.10 & 0.41 & -0.37 & -0.37 & -0.47 & -0.32 & -0.41 & -0.30 & -0.03 & $-0.49^{*}$ \\
\hline spi m² & & & & -0.10 & -0.02 & 0.00 & -0.22 & -0.14 & -0.28 & -0.39 & -0.36 & -0.10 & -0.26 & -0.22 & -0.27 \\
\hline SL & & & & & -0.12 & $0.71^{* *}$ & 0.24 & 0.22 & 0.41 & 0.27 & 0.18 & 0.33 & 0.27 & 0.07 & 0.26 \\
\hline NSS & & & & & & 0.10 & -0.02 & -0.39 & -0.02 & -0.15 & -0.21 & -0.25 & 0.02 & -0.11 & -0.24 \\
\hline NGS & & & & & & & 0.37 & 0.15 & 0.32 & 0.15 & 0.21 & 0.10 & 0.07 & 0.20 & 0.18 \\
\hline$N$ & & & & & & & & -0.34 & -0.29 & -0.33 & -0.18 & -0.31 & -0.25 & -0.10 & -0.31 \\
\hline$P$ & & & & & & & & & $0.82^{\star \star *}$ & $0.85^{\star \star *}$ & $0.89^{* * *}$ & $0.78^{\star * *}$ & $0.67^{* *}$ & $0.66^{* *}$ & $0.91^{* \star *}$ \\
\hline $\mathrm{K}$ & & & & & & & & & & $0.92^{* * *}$ & $0.83^{* * *}$ & $0.84^{* * *}$ & $0.85^{\star * *}$ & $0.66^{* *}$ & $0.83^{\star \star \star}$ \\
\hline $\mathrm{Ca}$ & & & & & & & & & & & $0.92^{* * *}$ & $0.83^{* * *}$ & $0.85^{* * *}$ & $0.65^{\star *}$ & $0.91^{* * *}$ \\
\hline $\mathrm{Mg}$ & & & & & & & & & & & & $0.74^{* * *}$ & $0.80^{* * *}$ & $0.82^{* * *}$ & $0.95^{\star \star \star}$ \\
\hline $\mathrm{Fe}$ & & & & & & & & & & & & & $0.86^{\star * *}$ & $0.62^{*}$ & $0.75^{\star \star \star}$ \\
\hline $\mathrm{Zn}$ & & & & & & & & & & & & & & $0.71^{* *}$ & $0.77^{* \star \star}$ \\
\hline $\mathrm{Cu}$ & & & & & & & & & & & & & & & $0.72^{\star *}$ \\
\hline
\end{tabular}

${ }^{*}$ signifficant at $10 \% ;{ }^{* *}$ signifficant at $5 \%$ and ${ }^{* * *}$ signifficant at $1 \%$.

There was a negative correlation between the test weight and Mn (Table 3). Other studies also reported a negative association between $\mathrm{Mn}$ and variables related to grain quality. In a study by WILSON et al. (1982), the seed's protein content correlated negatively with the plant's Mn content. COELHO et al. (2001) also reported a negative correlation between the Mn and protein content in wheat grains.

Therefore, the benefits of leaf inoculation were restricted to the improved absorption of different cationic macronutrients $\left(\mathrm{Ca}^{2+}\right.$ and $\left.\mathrm{Mg}^{2+}\right)$. On the other hand, $\mathrm{N}$ supply favored increases in grain yield, which was correlated to the number of grains per spike and to the leaf's $\mathrm{Cu}$ and $\mathrm{Mn}$ content.

\section{CONCLUSION}

Despite the water deficit in the experimental conditions, leaf application of $A$. brasilense did not allow the dose of $\mathrm{N}$ to decrease and even improved absorption of $\mathrm{Ca}$ and $\mathrm{Mg}$. The best responses were between 283 and $380 \mathrm{ml} \mathrm{ha}^{-1}$. Similarly, topdressing wheat with nitrogen fertilization altered the $\mathrm{Ca}$, $\mathrm{Mg}$, and $\mathrm{Cu}$ content in the leaves. The best responses were observed between doses 47 and $61 \mathrm{~kg} \mathrm{ha}^{-1}$.

$\mathrm{N}$ supply was responsible for increases in grain yield that were related to the increased number of grains per spike and to greater $\mathrm{Cu}$ and $\mathrm{Mn}$ content in the leaves. brasilense.

Nitrogen use efficiency decreased as the dose of $\mathrm{N}$ increased, regardless of leaf spraying with $A$.

\section{ACKNOWLEDGEMENTS}

The authors wish to thank the Coordination for the Improvement of Higher Education Personnel (CAPES) for providing financial support to the first author and GESSO, the Soil Research Group, at the State University of Maringá (UEM). We would also like to thank Mr. Leonel da Silva Feijo de Goes and Family for providing the area for field research.

\section{REFERENCES}

ABITRIGO 2017. Associação Brasileira da Indústria do Trigo. Importação e Exportação. Disponível em: http://www.abitrigo.com.br/estatisticas-importacao-e-exportacao.php. Acesso em: 02 fev. 2020.

ARAÚJO EO et al. 2013. Estado nutricional do milho em resposta à aplicação de nitrogênio e à inoculação com Azospirillum brasilense e Herbaspirillum seropedicae. In: XII Seminário Nacional Milho Safrinha. Resumos... Dourados: 
EMBRAPA \& UFGD. p.1-4.

BASHAN Y \& de-BASHAN L. 2010. How the plant growth-promoting bacterium Azospirillum promotes plant growth: A critical assessment. Advances in Agronomy 108: 77-136.

BESEN MR et al. 2018. Fontes minerais de nitrogênio na sucessão milho-trigo em sistema de plantio direto. Journal of Agronomical Sciences 7: 87-102.

CASANOVAS EM et al. 2002. Azospirillum inoculation mitigates water stress effects in maize seedlings. Cereal Research Communications 30: 343-350.

CASSÁN F et al. 2009. Cadaverine production by Azospirillum brasilense and its possible role in plant growth promotion and osmotic stress mitigation. European Journal of Soil Biology 45: 12-19.

CAZETTA DM et al. 2007. Resposta de cultivares de trigo e triticale ao nitrogênio no sistema de plantio direto. Científica 35: $155-157$.

CEPEA. 2018. Centro de Pesquisas Econômicas da Escola Superior de Agricultura Luiz de Queiroz. TRIGO/CEPEA: Oferta abundante pode pressionar rentabilidade do produtor em 2018. Disponível em: https://www.cepea.esalq.usp.br/br/releases/trigoperspec-2018-oferta-abundante-pode-pressionar-rentabilidade-doprodutor-em2018.aspx. Acesso em: 05 fev. 2020.

COELHO MAO et al. 2001. Composição mineral e exportação de nutrientes pelos grãos do trigo irrigado e submetido a doses crescentes e parceladas de adubo nitrogenado. Revista Ceres 48: 81-94.

CONAB. 2018. Companhia Nacional de Abastecimento. Acompanhamento da Safra Brasileira de Grãos $2018 / 19$. Brasília: CONAB. Disponível em: https://www.conab.gov.br/info-agro/safras/graos/boletim-da-safra-de-graos. Acesso em: 22 Mar. 2020.

CORREIA LV et al. 2020. Inoculation of wheat with Azospirillum spp.: A comparison between foliar and in-furrow applications. Journal of Agricultural Science 12: 194-199.

CREUS CM et al. 2004. Water relations and yield in Azospirillum-inoculated wheat exposed to drought in the field. Canadian Journal of Botany 82: 273-281.

DÍAZ-ZORITA M \& CANIGIA MFV. 2009. Field performance of a liquid formulation of Azospirillum brasilense on dryland wheat productivity. European Journal of Soil Biology 45: 3-11.

DOBBELAERE SA et al. 2002. Effect of inoculation with wild type Azospirillum brasilense and $A$. irakense strains on development and nitrogen uptake of spring wheat and grain maize. Biology and Fertility of Soils 36: 284-297.

DOORENBOS J \& KASSAN HA. 1979. Yield response to water. Paper 33. Rome: FAO Irrigation and Drainage. 193p.

ESPÍNDULA MC et al. 2010. Composição mineral de grãos de trigo submetidos a doses de sulfato de amônio e trinexapac-etil. Pesquisa Agropecuária Tropical 40: 513-520.

FAGERIA NK \& BALIGAR VC. 2005. Enhancing nitrogen use efficiency in crop plants. Advances in Agronomy 88: 97185.

FERNANDES MS. 2016. Integração de conhecimentos para uso eficiente do N na agricultura. In: MOREIRA FMS \& KASUYA MCM (Eds.). Fertilidade e biologia do solo: integração e tecnologia para todos. Viçosa: SBCS. p.174-195.

FUKAMI $\mathrm{J}$ et al. 2016. Acessing inoculation methods of maize and wheat with Azospirillum brasilense. AMB Express 6: 1-13.

GALINDO FS et al. 2019. Micronutrient Accumulation with Azospirillum brasilense Associated with Nitrogen Fertilization Management in Wheat. Communication in Soil Science and Plant Analysis 50: 2429-2441.

GALINDO FS et al. 2015b. Épocas de inoculação com Azospirillum brasilense via foliar afetando a produtividade da cultura do trigo irrigado. Revista Tecnologia e Ciência Agropecuária 9: 43-48.

GALINDO FS et al. 2015a. Efeito de épocas de aplicação foliar de Azospirillum brasilense nos teores de nutrientes do trigo irrigado. Revista Tecnologia e Ciência Agropecuária 9: 37-42.

HEINEMANN AB et al. 2006. Eficiência de uso da radiação solar na produtividade do trigo decorrente da adubação nitrogenada. Revista Brasileira de Engenharia Agrícola e Ambiental 10: 352-356.

KIM YC et al. 2012. Enhancement of plant drought tolerance by microbes. In: AROCA R. (Ed.). Plant responses to drought stress: from morphological to molecular features. Berlin: Springer Verlag. p.383-413.

LIBARDI VCM \& COSTA MB. 1997. Consumo d'água da cultura do trigo (Tricutum aestivum L.). Revista da FZVA 4: 1623.

LIU K et al. 2000. Inward potassium channel in guard cells as a target for polyamine regulation of stomatal movements. Plant Physiology 124: 1315-1326.

MALAVOLTA E et al. 1997. Avaliação do estado nutricional das plantas: Princípios e aplicações. Piracicaba: POTAFOS. 319p.

MARKS BB et al. 2015. Maize growth promotion by inoculation with Azospirillum brasilense and metabolites of Rhizobium tropici enriched on lipo-chitooligosaccharides (LCOs). AMB Express 5:1-11.

MENDES MC et al. 2011. Avaliação da eficiência agronômica de Azospirillum brasilense na cultura do trigo e os efeitos na qualidade de farinha. Pesquisa Aplicada \& Agrotecnologia 4: 95-110.

MORAGHAN JT \& MASCAGNI Jr HJ. 1991. Environmental and soil factors affecting micronutrient deficiencies and toxities. In: MORTVEDT JJ et al. (Eds.). Micronutrients in Agriculture. Madison: SSSA Book Series. p.371-425.

MOREIRA FMS \& SIQUEIRA JO. 2002. Microbiologia e Bioquímica do Solo. 2.ed. Lavras: Editora UFLA. 729p.

MOREIRA A et al. 2019. Copper fertilization in soybean-wheat intercropping under no-till management. Soil and Tillage Research 193: 133-141. 
MUNARETO JD et al. 2018. Compatibility of Azospirillum brasilense with fungicide and insecticide and its effects on the physiological quality of wheat seeds. Semina: Ciências Agrárias 39: 855-864.

NOZAKI MH et al. 2014. Efeito do Azospirillum spp. em associação com diferentes doses de adubação mineral na cultura do trigo. Ensaios e Ciência: Ciências Biológicas, Agrárias e da Saúde 17: 27-35.

OFFEMANN LC. 2015. Inoculação via sementes e foliar de Azospirillum brasilense na cultura do trigo, associado à fertilização nitrogenada. Dissertação (Mestrado em Agronomia). Marechal Cândido Rondon: UNIOSTE. 50p.

OKON Y \& KAPULNIK Y. 1986. Development and function of Azospirillum-inoculated roots. Plant and Soil 90: 3-16.

PEREIRA LC et al. 2017. Rendimento do trigo (Triticum aestivum) em resposta a diferentes modos de inoculação com Azospirillum brasilense. Revista de Ciências Agrárias 40: 105-113.

RIBEIRO RH et al. 2018. Seed and leaf inoculation with Azospirillum brasilense and increasing nitrogen in wheat production. Revista Brasileira de Ciências Agrárias 13: 1-8.

RONSANI SC et al. 2018. Adubação nitrogenada na produção de grãos e matéria seca de cultivares de trigo de duplo propósito. Revista de Ciências Agroveterinárias 17: 174-181.

ROLIM GS et al. 1998. Planilhas no ambiente Excel para os cálculos de balanços hídricos: normal, sequencial, de cultura e de produtividade real e potencial. Revista Brasileira de Agrometeorologia 6: 133-137.

SANTOS HG et al. 2013. Sistema Brasileiro de Classificação de Solos. 3.ed. Brasília: Embrapa. 342p.

SILVA SR \& PIRES JFL. 2017. Resposta do trigo BRS Guamirim à aplicação de Azospirillum, nitrogênio e substâncias promotoras do crescimento. Revista Ciência Agronômica 48: 631-638.

SBCS/NEPAR. 2017. Sociedade Brasileira de Ciência do Solo. Núcleo Estadual do Paraná. Manual de adubação e calagem para o estado do Paraná. Curitiba: SBCS. 482p.

TIEN TM et al. 1979. Plant growth substances produced by Azospirillum brasilense and their effect on the growth of pearl millet (Pennisetum americanum L.). Applied and Environmental. Microbiology 37: 1016-1024.

VERESOGLOU SD \& MENEXES G. 2010. Impact of inoculation with Azospirillum spp. on growth properties and seed yield of wheat: a meta-analysis of studies in the ISI Web of Science from 1981 to 2008. Plant and Soil 337: 469-480.

YANG J et al. 2009. Rhizosphere bacteria help plants tolerate abiotic stress. Trends in Plant Science 14: 1-4.

WILSON DO et al. 1982. Changes in soybean seed oil and protein as influenced by manganese nutrition. Crop Science 22: 948-952. 